\section{THE SMITHSONIAN INSTITUTION.'}

II.

The System or Admisistration.

THE Smithsonian Institution was formally established by the Act of Congress approved August 10, 1846. As defined in the fundamental Act the "Establishment," a body which is in fact "the Institution," is composed of the President of the United States, who is presiding officer ex officio, the Vice-President, the Chief Justice, and the members of the Cabinet; and the body this constituted is made responsible for the duty of "the increase and diffusion of knowledge among men."

In addition to the "Establishment," the Act provirles for a "Board of Regents," by whom the business of the Institution is administered, composed of the Vice-P'resident of the United States, the Chief Justice of the Supreme Courts, three members of the Senate, three members of the House of Representatives, and six citizens, no two of whom may be from the same State, though two must be residents of the District of Columbia.

The presiding officer of the Regents is the Chancellor, whom they may elect from their own number. This position has, however, customarily been held by the Vice-President or by the Chief Justice. The executive officer is the Secretary of the Institution, who is elected by the Regents, and is also the Secretary of that Board. The duties and responsibilities of the Secretary are, as has already been explained, such as in other institutions usually belong to the office of Director. He presents to the Regents an annual report upon the operations, expenditures, and condition of the establishment, which is transmitted by the Board to Congress for publication. By special Act of Congress of I 884 an acting-Secretary is provided, in case of the absence or disability of the Secretary, the designation being left with the Chancellor of the Institution. There is at present but one assistant-Secretary, who is in charge of the National Museum.

The annual meeting of the Regents is held in January; their executive committee of three members meet quarterly.

The building occupied by the Institution, and bearing its name, is an ornate structure of Seneca brown stone, occupying a prominent position in the "Mall," which extends from the Capitol to the Washington Monument, in the square known as the Smithsonian Park. This edifice, planned by James Renwick, was begun in 1847 and completed in 1855 . Features from different periods of Romanesque styles are combined in its architecture; but its exterior, owing chiefly to the irregular skyline, is very picturesque and pleasing.

The eastern wing of the building, for so many years the hospitable home of Prof. Henry, has been reconstructed inkernally, and the offices of the Institution are all established within its walls. The remainder of the building is occupied by the laboratories and exhibition halls of the National Museum.

Another building of brick, 325 feet square, was built east of the Smithsonian in $\mathrm{I} 88 \mathrm{I}$, for the reception of a portion of the Museum collections.

\section{The Objects of the Institution.}

The objects of the Institution, as defined by Henry, are, first, to increase knowledge by original investigations and study either in science or literature; and, second, to diffuse knowledge, not only through the United States, but everywhere, especially by promoting an interchange of thought among those prominent in all nations. No restriction is made in favour of any one branch of knowledge.

The leading features of the plan of Prof. Henry were, in his own words, "to assist men of science in making original researches, to publish them in a series of volumes, and to give a copy of them to every first-class library on the face of the earth." There are not many scientific investigators in the United States to whom a helping hand has not at some time been extended by the Institution, and the hand has often reached across the Atlantic. Books, apparatus, and laboratory accommodation have been supplied to thousands, and each year a certain number of money grants have been made. Not less important has been the personal encouragement afforded, and the advice given in the tens of thousands of letters of information written in response to inquiries.

It is not, as some persons suppose, a teaching institution, nor

1 By Dr. G. Brown Goode. (Continued from page 26r.)

NO. I 369 , vOL. 53$]$ does it receive students. It constantly aids, however, in the improvement of the educational system of the country. ${ }^{1}$

An important feature in the educational work of the Institution has been its participation in the various International Expositions. It was represented at Philadelphia in 1876 , Berlin, I880 ; London, I883 ; New Orleans, I885; Cincinnati, I889; Madrid, I892 ; Chicago, I893; Atlanta, I895; and has received many medals and diplomas of commendatory nature upon these occasions.

\section{The Publications.}

The publications are numerous, and include many important and authoritative works. There is no restriction as to subject, and they consist of memoirs upon archeology, ethnology, botany, zoology, geology, palæontology, meteorology, magnetics, physics, physiology, and philology, and many other branches of investigation.

These books are practically given away, for although there is a provision for their sale at cost price, only a few hundred dollars worth are soid each year. They are regularly distributed to about 4000 institutions in all parts of the world, and are sup. plied also to numerous private investigators. There are several series, the aspect of which must be familiar to every observing person who has ever spent a day among the shelves in any American library of respectable standing.

(I) The Amnual Report of the Regents to Congress, of which the forty-ninth, that for 1894 , is now in press. Since 1884 the report of the Museum has been printed in a separate volume (F'art II. ). ${ }^{2}$

(2) The Smithsonian Contributions to Knowledge, thirtytwo volumes in quarto, containing over 7000 pages and many fine plates. ${ }^{3}$

(3) The Smithsonian Miscellaneous Collections, in thirty-five octavo volumes, aggregating about $\mathbf{2 2}, 000$ pages. ${ }^{4}$

(4) The Bulletins of the National Museum, fifty in number, beginning in $1875 .^{\circ}$

(5) The Proceedings of the National Museum, including already I IOo separate papers, embraced in seventeen annual volumes, beginning in $1878 .{ }^{\circ}$

(6) The Annual Reports of the Bureau of Ethnology, beginning in 1879 , and forming a series of twelve illustrated volumes in royal octavo. ${ }^{7}$

(7) The Bulletin of the Bureau of Ethnology, of which twentysix numbers have appeared. ${ }^{8}$

The value of the books distributed since the Institution was opened has been nearly $\mathrm{r}, 000,000$ dollars, or nearly twice the original bequest of Smithson. ${ }^{y}$ Many of the publications in each of these series are now out of print.

\section{THE Library.}

One of the most important features of the Institution is the library which has grown up under its fostering care. For nearly fifty years its publications have been distributed throughout the world to almost every :scientific and literary establishment of good repute. In return for these, and by purchase, it has received the great collection of books which forms its library, and which is one of the richest in the world in the publications of learned societies, and therefore of inestimable value, contain. ing as it does the record of actual progress in all that pertains to the mental and physical development of the human family, and affording the means of tracing the history of every branch of

1 The Institution supports a table at the International Zoological Station in Naples for the benefit of naturalists. There is an assembly hall in the Museum building, in which meetings of scientific bodies of national scope are held. Here the National Academy of Sciences holds its annual meeting every April, and the American Historical Association (which is by law affiliated with the Institution) its December meeting. Here also each year a course of popular scientific lectures is delivered under the direction of the scientific societies of Washington

2 "Public Documents" printed by order of Congress, and distributed in large editions.

3 Published at the cost of the Smithsonian Fund, and not "Public

Documents."
4 lbid.

5 Published in a limited edition from a special appropriation, and not "Congressional Documents."

6 Tbit.

7 "Public Documents" printed by order of Congress, and distributed in large editions.

8 The Bureau also supervises a series of quarto volumes, bearing the title "Contributions to North American Ethnology," begun in 1877 by the U.S. Geographical and Geological Survey, of which nine have been issued.

9 This estimate is based upon the prices which are charged for the books by second-hand dealers, as shown in their sale catalogue. 
positive science since the days of the revival of letters until the present time.

This library was, in 1865 , deposited at the Capitol, as a portion of the Congressional Library.

The Smithsonian Collection, which includes more than three hundred thousand volumes and parts of volumes, constituting perhaps one-fourth of the National Library, is to be installed in a special stack-room of its own upon the main floor of the new Library Building, with a commodious reading-room adjacent for the use of special students. The rapidity with which it is increasing is indicated by the fact that in $1894,37,952$ titles were added. ${ }^{1}$

The Institution has probably done more towards building up a great library in Washington than would have been possible had all its income been devoted strictly to library work, as was at one time seriously proposed.

\section{The National, Museum.}

The Smithsonian Institution is the custodian of the National Museum, which is the only lawful place of deposit of "all objects of art and of foreign and curious research, and all objects of natural history, plants, and geological and mineralogical specimens, belonging to the United States." The nucleus of

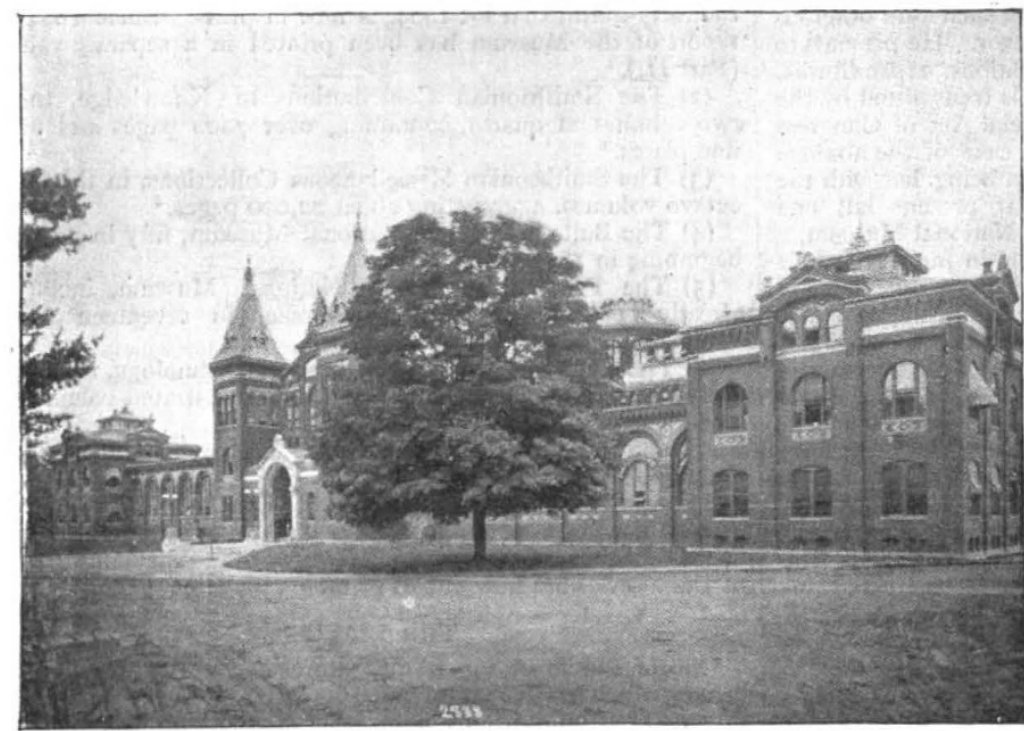

Frg. 6.-The New Museum Building.

the collections consists of the specimens brought home by the Wilkes and other exploring expeditions, but for many years the Museum was supported entirely at the expense of the Smithson Fund, and a considerable portion of the collections is the property of the Institution. Since I88I, the entire expenses of administration have been met by Congressional appropriations. The appropriations from 1858 to 1880 were only sufficient to meet these expenses in part.

Prof. Huxley defines a museum as " a consultative library of objects." The National Museum is such a consultative library, and it is a great deal more. It is an agency for the instruction of the people of the whole country, and it keeps in mind the needs of persons whose lives are not occupied in the study of science as well as those of the professional investigator and teacher.

Its benefits are extended without cost or reserve to hundreds of thousands of visitors from all parts of the United States who pass through its doors each year, as is shown in the following table :

1 The working libraries of the National Museum and the Bureau of Ethnology are distinct from the general Smithsonian Library, and are separately administered. All of these are placed at the service of advanced students and specialists.

NO. I 369 , vOL. 53]

\begin{tabular}{|c|c|c|c|c|c|c|}
\hline Year. & $10 \mathrm{at}$ & $\begin{array}{c}\text { er of } \\
\text { New } \\
\text { Building. }\end{array}$ & & $\begin{array}{l}\text { since I8 } \\
\text { Old } \\
\text { Building. }\end{array}$ & & Tot: \\
\hline 88 I $\quad \ldots$ & $\ldots$ & I 50,000 & $\ldots$ & 100,000 & $\ldots$ & 250,000 \\
\hline & $\ldots$ & I 67,455 & $\ldots$ & I 52,744 & $\ldots$ & 320,199 \\
\hline 383 & $\ldots$ & 202,188 & $\ldots$ & 104,823 & $\ldots$ & 307,011 \\
\hline 384 (half- & year) & $97,66 \mathrm{I}$ & $\ldots$ & $4 \mathrm{I}, 565$ & $\ldots$ & I 39,226 \\
\hline $84-85$ & $\ldots$ & ${ }^{*} 205,026$ & $\ldots$ & 102,093 & $\ldots$ & 307,119 \\
\hline $385-86$ & $\ldots$ & I 74,225 & $\ldots$ & 88,960 & $\ldots$ & 263,185 \\
\hline $86-87$ & $\ldots$ & 216 & $\ldots$ & $98,55^{2}$ & $\ldots$ & $315,1 I_{4}$ \\
\hline $387-88$ & $\ldots$ & 249,665 & $\ldots$ & 102,863 & $\ldots$ & 35 \\
\hline 89 & $\ldots$ & *374 & $\therefore$ & I 49,618 & $\ldots$ & $46 \mathrm{I}$ \\
\hline 90 & $\ldots$ & 27 & $\ldots$ & 120 & $\ldots$ & 395,218 \\
\hline & $\ldots$ & & $\ldots$ & III & $\cdots$ & \\
\hline & $\ldots$ & 269 & $\ldots$ & I I 4 , & $\cdots$ & 384,642 \\
\hline 93 & $\ldots$ & *319 & $\ldots$ & I74 & $\ldots$ & 494 , I I 8 \\
\hline & $\ldots$ & & $\ldots$ & & $\ldots$ & \\
\hline & $\ldots$ & 196 & $\ldots$ & 109,847 & $\cdots$ & 306,222 \\
\hline & & & & & & \\
\hline
\end{tabular}

And also through the distribution of the duplicate specimens in the Museum, which are made up into sets, accurately named, and given to public institutions in all parts of the country.

The history of the Museum is divided into three periods: First, that from the foundation of the Smithsonian Institution to 1857 , during which time specimens were collected purely and solely to serve as materials for research, no special effort having been made to publicly exhibit them or to utilise them, except as a foundation for scientific description and theory. Second, the period from 1857 , when the Institution assumed the custody of the "National Cabinet of Curiosities," to 1876 . During this period the Museum became a place of deposit for scientific material which had already been studied; this material, so far as practicable, being exhibited to the public, and thus made to serve an educational purpose. Third, the present period, beginning in the year 1876 , during which the Museum has entered upon a career of active work in gathering collections and exhibiting them on account of their educational value.

During the first period, the main object of the Museum was scientific research; in the second, the establishment became a museum of record as well as of research; while in the third period there is growing up also the idea of public education.

The three ideas, Record, Research and Education, co-operative and mutually helpful as they are, are essential to the development of every great museum. The National Museum endeavours to promote them all.

It is a Museum of Record, in which are preserved the material foundations of an enormous amount of scientific knowledge - the types of numerous past investigations. This is especially the case with those materials that have served as a foundation for the reports upon the resources of the United States.

It is a Museum of Research, which aims to make its contents serve in the highest degree as a stimulus to inquiry and a foundation for scientific investigation. Research is necessary in order to identify and group the objects in the most philosophical and instructive relations, and its officers are therefore selected for their ability as investigators, as well as their trustworthiness as custodians.

It is an Educational Museum, through its policy of illustrating by specimens every kind of natural object and every manifestation of human thought and activity, of displaying descriptive labels adapted to the popular mind, and of distributing its publications and its named series of duplicates.

The collections are installed, in part, in the Smithsonian 
building and, in part, in the large building adjacent, covering three and a half acres of ground, which was erected in 1881 to afford temporary accommodation for the overflow until such time as an adequate new building could be constructed.

The number of specimens in the various departments of the Museum, in 1894, is shown in the following table:

Statistics of the National Coljections.

Arts and Industries.

Historical collections, coins, medals, \&c. 29,998

Musical instruments $\quad \ldots \quad \ldots \quad \ldots, \quad$ I,219

Modern pottery, porcelain, bronzes, \&c.... 3,583

$\begin{array}{llllll}\text { Graphic arts } & \ldots & \ldots & \ldots & \ldots & \text { I,704 }\end{array}$

$\begin{array}{lllll}\text { Physical apparatus... } & \ldots & \ldots & \ldots & 366\end{array}$

$\begin{array}{lcccr}\text { Transportation and engineering } & \ldots & \ldots & \text {... } & \text { 1,793 } \\ \text { Naval architecture } . . & \ldots & \ldots & \ldots & 802\end{array}$

$\begin{array}{lllllll}\text { Fisheries } & \ldots & \ldots & \ldots & \ldots & \ldots & \text { I0,080 }\end{array}$

$\begin{array}{rrrrrr}\text { Animal products } & \ldots & \ldots & \ldots & \ldots & 10,080 \\ & \ldots & \ldots & \ldots & 3,028\end{array}$

$\begin{array}{rrrrr}\text { Domestic animals } \ldots & \ldots & \ldots & \ldots & 3,028 \\ \end{array}$

$\begin{array}{lllll}\text { Chemical products... } & \ldots & \ldots & \ldots & 1,309\end{array}$

$\begin{array}{llllll}\text { Materia medica } & \ldots & \ldots & \ldots & \ldots & 6,317\end{array}$

$\begin{array}{lllllll}\text { Foods } & \ldots & \ldots & \ldots & \ldots & \ldots & 6,317 \\ \text { Textill } & \ldots & \ldots & \ldots & \ldots & \ldots & \text { I III }\end{array}$

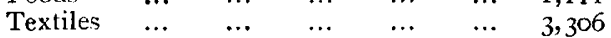

$\begin{array}{llllllr}\text { Forestry } & \cdots & \cdots & \ldots & \ldots & \ldots & 3,306 \\ \end{array}$

$\begin{array}{lllllll}\text { Ethnology } & \ldots & \ldots & \ldots & \ldots & \ldots & 423,000\end{array}$

Oriental antiquities and religious ceremonial... 4, 445

$\begin{array}{lllll}\text { Prehistoric anthropology } & \ldots & \ldots & \ldots & \text { I } 53,424\end{array}$

American aboriginal pottery $\quad \ldots . \quad \ldots . \quad \ldots \quad 33,293$

$\begin{array}{lllllll}\text { Mammais } & \ldots & \ldots & \ldots & \ldots & \ldots & \mathbf{1 2}, 948\end{array}$

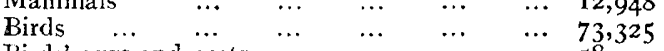

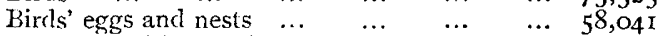

$\begin{array}{lllll}\text { Reptiles and batrachians } & \ldots & \ldots & \ldots & 34,215\end{array}$

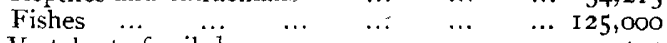

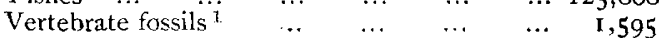

Mollusks (including Cenozoic fossils) ... $\quad \ldots \quad$... 510,256

Insects $\ldots \begin{array}{lllllll}\ldots & \ldots & \ldots & \ldots & \ldots & \ldots & 6 \text { I0, } 000\end{array}$

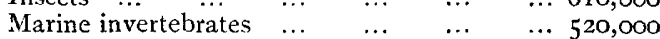

$\begin{array}{llllll}\text { Comparative anatomy } & \ldots & \ldots & \ldots & \ldots & 520,000 \\ & \ldots & \ldots & \ldots & 14,828\end{array}$

$\begin{array}{llllll}\text { Palrozoic fossils } & \ldots & \ldots & \ldots & \ldots & 95,63 \text { I }\end{array}$

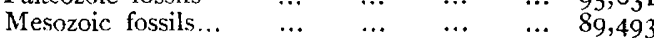

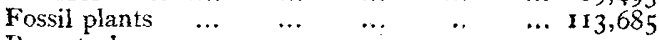

$\begin{array}{lllllll}\text { Ressil plants } & \ldots & \ldots & \ldots & \ldots & \ldots & 113,685 \\ \text { Recent plants } & \ldots & \ldots & \ldots & \ldots & \ldots & 252, \text { I I }\end{array}$

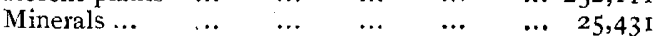

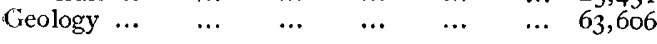

$$
\text { Total } \quad \ldots \quad \overrightarrow{3,279,53 \mathrm{I}}
$$

The importance of these collections is greatly enhanced by this fact, that they inciude many thousands of types of the original descriptions of the pioneers of American natural history -Audubon, Baird, Agassiz, Girard, Cope, Marsh, Gray, Young, Dana, Gill, Jordan, and many more, and as such constitutes an important part of the foundation of our systematic zoology and botany.

The intrinsic value of such material as this cannot well be expressed in figures. There are single specimens worth hundreds, others worth thousands of dollars, and still others which are unique and priceless. Many series of specimens, which owe their value to their completeness and to the labour which has been expended on them, are priceless. 'The collections at a forced sale would realise more than has been expended on them, and a fair appraisal of their value would amount to several millions of dollars.

In the clirect purchase of specimens but little money has been spent, less perhaps in fifty years than either France, England, Germany, or Austria expends in a single year on similar objects. The entire Museum is the outgrowth of Government expeditions and expositions, and of the gifts prompted by the generosity of the American people.

\section{The Bureau of Exchanges.}

The Smithsonian system of international exchanges, begun in I 852, had for its object the free interchange of scientific material between scientific institutions and investigators in the United States and those in foreign lands. For this purpose it established correspondence with scientific societies, literary and learned men all over the world, until there is no civilised country or people, however remote, upon the surface of the planet, so far as is

1 Only that portion of the Collection which is in Washington is included.

No. I 369 , vOL. 53] known, where the Institution is not represented. The list of correspondents has lengthened until those external to the country alone number nearly 17,000 , while the total number is about 24,000 .

Many of the principal steamship companies gave generous aid in recognition of this disinterested work by granting important concessions of free freight. The United States and foreign Governments permitted the entrance through their Customs services of Smithsonian exchange boxes, and the Institution was enabled to distribute its exchange packages in this country, without expense to its funds, under the franking privilege.

In recent years the Smithsonian has been recognised by the United States Government as being in charge of its official Exchange Bureau, through which the publications of Congress are exchanged for those of foreign Governments, and by a formal treaty it acts in an official capacity as intermediary between the learned bodies and literary and scientific societies, \&c., of the contracting States for the reception and transmission of their publications.

The Exchange Service has become a most valuable adjunct to educational interests, and there are few important libraries or workers in science, either at home or abroad, who have not had direct experience of its benefits.

The rules established for its control provide for the distribution to any accessible point abroad of books, pamphlets, charts, and other printed matter sent as donations or exchanges, and without expense to the sender beyond that of the delivery of the packages to the Snithsonian Institution in Washington, and also without expense to the receiver, except in some instances the small cost of delivery from the Smithsonian agent or correspondent nearest at hand. Similar material sent from abroad to this country is forwarded to the recipient without expense to him, the packages having been delivered free of freight charges to a foreign agent or correspondent of the Institution.

A scientific society or individual in the United States desiring to take advantage of the Exchange Service should have each of the packages transmitted strongly wrapped and separately and legibly addressed, being careful to give the full local address, and should send them in bulk, carriage prepaid, to the Institution in Washington. The separate packages should not exceed one-half of one cubic foot in bulk, and they should not contain letters or written matter.

Transmissions from abroad are received by freight in large boxes, and are distributed in the United States under frank by registered mail, a record first having been made of the name of the sender and of the address of each package. A receipt card, returnable by mail without postage, is sent with each of these packages, and should be forwarded at once by the recipient in acknowledgment of the package.

The Institution and its agents will not knowingly receive for any address purchased books, nor apparatus and instruments, philosophical, medical, \&c. (including microscopes), whether purchased or presented; nor specimens of natural history, except where special permission from the Institution has been obtained.

The operations of this Bureau have affected most beneficially the libraries of all learned institutions in America. In 1867 Congress assigned to the Institution the duty of exchanging fifty copies of all public documents for similar works published in foreign countries. Finally in 1889 a definite treaty, made previously at Brussels, was formally proclaimed by the President of the United States, wherein the United States Government, with a number of others, undertook the continuation of the exchange service on a more extensive basis. Out of this has grown the Bureau of International Exchanges, for the maintenance of which Congress partially provides by annual appropriation. From 1852 to 1895 the Smithsonian exchange service handled I, 459,448 packages, and for three years past the weight of boolis passing through this office has been considerably over one hundred tons annually.

\section{Spectal Gifts and Trusts.}

The authority of the Institution to undertake the administration of financial trusts for any purpose within the scope of its general plan, preserving in connection with each fund the name of the person by whom it was established, has been recognised by Congress.

There is no institution in the world which is more favourably 
situated for the administration of trusts of this character, and this privilege has, within the past few years, been accepted by several benefactors.

Dr. Jerome H. Kidder, of Washington City, bequeathed, in I889, 5000 dols. for the purpose of an astro-physical observatory.

Dr. Alexander Graham Bell, in 1889 , gave 5000 dols. to the Secretary for his personal use in physical investigation, which has been transferred by him to the credit of the Institution, and devoted to physical work.

Mr. Thomas G. Hodgkins, of Setauket, N.Y., gave, in I 89 I, nearly 250,000 dols., a portion of the income from which is to be applied to the investigation of atmospheric air. ${ }^{1}$

Robert Stanton Avery, of Washington City, who died in I 894, left property then estimated to be worth at least 50,000 dols. to provide for special investigations.

There have also been many valuable gifts to the Museum, such as that of Dr. Isaac Lea, of Philadelphia, who gave his great collections of mollusks, and of gems and precious stones ; that of Mr. Joseph Harrison, of Philadelphia, consisting of the collection of Indian portraits painted by George Catlin; that of Mr. R. D. Lacoe, of Pittston, Pa., the largest existing collection of American fossil plants; and the collections of American birds' eggs given by Major Charles Bendire, U.S.A., and Dr. William H. Ralph, of Utica, N.Y.

\section{The Astro-Physical ObSERvatory.}

The Astro-physical Observatory was established in I891, under the immediate direction of the present Secretary. The expense of maintenance has since been provided for by a small appropriation from Congress. Here is carried on work corresponding to that of similar institutions maintained by the principal European Governments, and on a much less expensive scale, though not less effectively.

Since astro-physics is almost the newest of sciences, it may not be amiss to give here a brief description of the purposes of this observatory:

"Within the past generation," we are told, "and almost coincidentally with the discovery of the spectroscope, a new branch of astronomy has arisen, which is sometimes called astro-physics, and whose purpose is distinctly different from that of finding the places of the stars, or the moon, or the sun; which is the principal end in view at such an observatory as that, for instance, at Greenwich.

"The distinct object of astro-physics is, in the case of the sun, for example, not to mark its exact place in the sky, but to find out how it affects the earth and the wants of man on it how its heat is distributed, and how it in fact affects not only the seasons and the farmer's crops, but the whole system of living things on the earth, for it has lately been proven that in a physical serse it, and almost it alone, literally first creates and then modifies them in almost every possible way.

"We have, however, arrived at a knowledge that it does so, without yet knowing in most cases how it does so, and we are sure of the great importance of this last acquisition, while still largely in ignorance how to obtain it. We are, for example, sure that the latter knowledge would form, among other things, a scientific basis for meteorology, and enable us to predict the years of good or bad harvests, so far as these depend on nat ural causes, independent of man, and yet we are still very far from being able to make such a prediction, and we cannot do so til we have learned more by such studies as those in question. Knowledge of the nature of the certain, but still imperfectly understood dependence of terrestrial events on solar causes is, then, of the greatest practical consequence.

"It has been observed that this recent science itself was almost coeval with the discovery of the spectroscope, and that instrument has everywhere been largely employed in most of its work. Of the heat which the sun sends, however, and which, in its terrestrial manifestations, is the principal object of our study, it has long been well known that the ordinary spectroscope could recognise only about one-quarter, three-quarters of all this solar heat being in a form which the ordinary spectroscope cannot see nor analyse, lying as it does in the, till lately, almost unknown ' infra-red' end of the spectrum, where neither the eye nor the photograph can examine it."

This Observatory in Washington has been continuing the 1 A prize of ro,oon dols., derived from this fund, was awarded August 6 , af covery of Argon, a hitherto unknown element in the atmosphere.

No. 1369 , vol. 53$]$ famous researches in regard to that invisible portion of the solar spectrum which lies beyond the limit of the red, which had been begun by Mr. Langley while director of the Allegheny Observatory. The exploration of " this great unknown region," which was first rendered possible by the invention of the bolometer, is now being carried still further by means of a new method, much perfected during the last four years, which has rendered it possible to produce a complete map by an automatic and absolutely trustworthy process, which shows the lines which resemble the so-called Fraunhofer lines in the upper spectrum. The results already attained are believed to be the most im portant which have ever been reached in regard to that region of the spectrum of which so little is known, and which includes the greater portion of all those energies of the sun which, through its heat, affect climate and the crops, and are thus related not only to questions of abstract interest, but to utilities of national importance.

\section{Tire National, Zoological, Park.}

The National Zoological Park was established by Congress in 1890 , as a result of the desire to secure the preservation of such American animals as are upon the verge of extinction and will soon vanish for ever if something is not done to protect them, and occupies a tract nearly twice as extensive as that of any zoological garden in the world; this includes one hundred and sixty-seven acres upon Rock Creek, only two miles north of the Executive Mansion, at the centre of the city. The site has admirable natural advantages, and much has already been done in the opening of drives and the construction of buildings.

When Congress was asked to appropriate funds for this Park, it was in view of the fact that many North American animals, constituting a part of the national wealth, and formerly occupying a large portion of its domain, are threatened with speedy extinction.

The buffalo, the beaver, the wapiti, the moose, and many other species, which until lately were abundant east of the Mississippi, are each year becoming rarer. On the Pacific Coast the sea-elephant is gone, and the walrus practically so, and the sea-otter, the fur-seal, and the sea-lion rapidly disappearing. The passenger-pigeon and the Carolina parrakeet are almost gone. It was urged upon Congress that unless steps were speedily taken, these races must perish.

The reservation of the Yellowstone National Park as a great game preserve was an important start in this direction, but the very immensity of the reservation seems to threaten the defeat of the plan, for the animals cannot be protected from marauders, and are being rapidly destroyed. To retard their extinction and to provide opportunities for their study, was the intention of those who first advocated the establishment of a preserve near Washington large enough to keep the animals as close to natural conditions as is possible, and the project seems to have been even more important than was at first supposed.

A small representative collection of native American animals has already been formed, including about five hundred individuals, among them a fine herd of young elk and a small herd of buffaloes; but the annual appropriations have not been sufficient to permit satisfactory progress.

\section{The Bureau of American Ethnology.}

The Bureau of Ethnology is an outgrowth of activities beginning early in the history of the Institution, which has from the very outset devoted much attention to the native American races.

The special work of the Bureau in its present form was begun in 1872 , in response to a request from the Commissioner of Indian Affairs, who desired trustworthy information concerning the affinities of the Indian tribes, to serve as a guide in grouping them on the reservations. The question was referred by the Secretary of the Smithsonian Institution to Major J. W. Powell, then engaged, under the direction of the Institution, in explorations in the south-west. Combining the vocabularies and other manuscipts already in possession of the Institution, he prepared a report showing the character and extent of existing information, and the manner in which it was possible to utilise this in the segregation of the Indian tribes, at the same time suggesting plans for the completion of the work of classification.

This was the beginning of the Bureau, which since 1879 has been supported by special appropriations from Congress, with the understanding that the research should be so extended as to 
embrace the habits and customs of the American Indians, their tribal organisations and government, and their myths and ceremonials.

Najor Powell was made director, and no one could have been better fitted for the task. For more than thirty years he had been a student of the native races of this continent. $\mathrm{He}$ and his associates in the Bureau have succeeded in placing on record, before it was too late, a vast number of facts in regard to the Indians. The Annual Reports of the Bureau, twelve in number, and nine volumes of Contributions to North American Ethnology, with the Bulletin of the Bureau, form a considerable library in themselves. The archives still contain much unpublished material, including hundreds of vocabularies.

A complete linguistic classification of the native languages of the United States has been prepared by the director, and an effective classification of the tribes on the reservation, reducing materially the danger of warlike outbreaks, has already been accomplished.

\section{Explorations.}

The promotion of exploration has, from the beginning, been an important feature in the work of the Institution, and grants of money and loans of apparatus have been made to many hundreds of explorers, who have thus been enabled to contribute to the knowledge of the zoology, botany and ethnology of the American continent. Much has also been done in supplying scientific apparatus to the officers of the various Government surveys, which, in early days, were very often equipped only for geographical work. The Naval Astronomical Expedition to Chili was supplied by the Institution with a telescope and other apparatus, which was afterwards bought by the Government of Chili for the National Observatory at Santiago. The medical officers of the numerous surveys preliminary to the building of the transcontinental railroads, and those of the several boundary surveys, thus equipped for natural history work, made vast collections.

Nembers of the Smithsonian staff have frequently been detailed to serve as tidal or meteorological observers, under other departments of the Government, in remote localities, for the purposes of exploration. The important early explorations of John Xantus on the extremity of the Lower Californian Peninsula, and of Turner, Nelson, Murdoch, Kumlien, and others in the Arctic regions, were effected in this manner, as well as the earlier and more important work of Kennicott, Dall and Bannister, in Alaska, in connection with the Russian Telegraph Expedition.

On the staff of the Bureau of Ethnology important explorations of the western portion of the continent have been made, especially those of the Stevensons, Cushing, Fewkes, and the Nindeliffs, among the Pueblo people and the ruins of the southwest; those of Holmes among the prehistoric quarry sites and villages of the eastern part of the continent; those of Thomas among the mounds of the Mississippi Valley, and of McGee among the Papago and Seri Indians of the Mexican boundary; and the notable explorations of Major J. W. Powell among the tribes of Utah, California, Arizona and New Mexico.

The expeditions of Rockhill in Tibet, of Jouy in Korea, of Abbot and Chanler in Eastern Africa and Kashmir, Madagascar and the islands of the Indian Ocean, have been indirectly under the auspices of the Institution, and allusion should also be made to the visit of Major Dutton to the Hawaiian Islands for the study of volcanic phenomena, which was carried on directly at the expense of the Smithsonian Fund.

The Institution participated also in fitting out the Arctic Expedition of Kane, Hayes and Hall.

\section{The Promise of the Future.}

At the time of the Smithson bequest, the endowment of research had scarcely been attempted in America. There were schools and colleges in which science was taught, and certain of the teachers employed in these institutions were engaged in original investigation. There were a few young and struggling scientific societies, very limited in extent and influence, but at that time the chief outcome of American scientific work. Science in America was an infant in swaddling clothes. Fifty years have passed, and American science now stands by the side of the science of Great Britain, of Germany, of France, a fellow worker competing in nearly every field of research.

The Smithsonian Institution did what was, at the time of its organisation, absolutely indispensable to the rapid and symmetrical development of American scientific institutions, and but for it, science in America would no cloubt have advanced with much less rapidity. It is also certain that the progress of American science has had an immense influence upon the welfare of America in every department of intellectual and industrial activity, and also a reflex action upon the scientific and industrial progress of the entire world.

This year the Smithsonian Institution will celebrate the end of its first half-century. A special volume will be published to commemorate the event, and two memorial tablets will be erected in honour of the founder in the city of Genoa, where he died, June 26, I829; one in the English church, and one upon his tomb in the beautiful little English cemetery on the cypressclad heights of San Benigno.

It is interesting to remember that in September next will occur not only the semi-centenary anniversary of the birth of the Institution founded in the City of Washington by Smithson, but also the centenary of the delivery of that immortal address in which Washington so forcibly recommended to his countrymen "to promote as an object of the highest importance INSTITUTIONS FOR THE INCREASE AND DIFFUSION OF KNOWLEI)GE."

\section{UNIVERSITY AND EDUCATIONAL INTELLIGENCE.}

CAMBRIIGE. - The Council of the Royal Geographical Society offer in the present academical year a Studentship of $£$ 100, to be used in the geographical investigation (physical or historical) of some district approved by the Council. Candidates must be members of the University of not more than eight years'standing from matriculation, who have attended the courses of lectures given in Cambridge by the University Lecturer in Geography. Applications should be addressed to the Vice-Chancellor not later than the last day of the full Lent Term, March I3, I896.

Lord Haisbury has been elected Chairman of the Council of the City and Guilds of London Institution for the Advancement of Technical Education.

The Technical World has extended its sphere of usefulness. Henceforth it will be the newspaper for secondary and technical education broadly defined. It has been accepted as the official organ of the Association of Headmasters, and of the Association of Organising Secretaries and Directors. The general policy of our contemporary will be to support the conclusions of the Royal Commission on Secondary Education, by which we understand that it will exert its influence in co-ordinating the work of secondary education. With one paragraph in the announcement of the enlargement of the journal we are in entire agreement; it is this: "That the organising secretaries and directors should have an official organ will serve to remind them (a fact which a few are prone to forget) that they have duties not only to their own counties and committees, but to each other and to higher education generally. The more they co-operate, and within limits agree, the better will be the individual work of each."

WISE words were spoken by Sir Henry Fowler last week, while commenting upon the report of the Wolverhampton Chamber of Commerce. Referring to the necessity for technical education, he remarked: "In this respect foreigners are ahead of England, and Chambers of Commerce might attach more importance to the point. In foreign countries they make greater sacrifices for it and do not grumble at the expense. In England we are now waking up to the importance of it, but we want technical education on a very much larger scale than we have as yet got it. We want it very much on the lines which the Committee of the Chamber of Commerce in their report point out, namely, technical instruction for foremen and better-class artisans. In a competition between two manufacturing countries, the country where the manufacturing population has the better technical education is more favourably placed in connection with its operations, and has a distinct advantage in the markets of the world." We are doing a little, it is true, to advance technical and scientific knowledge, but much of the money allocated to local authorities for technical education is being frittered away. Many Technical Instruction Committees are incapable of organising a scheme of instruction which will prove of permanent benefit to industry. Instead of concentrating their attention upon a few subjects, and supplying effective education in them, they devote $£$ IO or $£ 20$ to each of a multiplicity 